\title{
Vegetative Regeneration Capacities of Five Ornamental Plant Invaders After Shredding
}

\author{
Arnaud Monty - Marie Eugène - Grégory Mahy \\ Received: 4 May 2014 / Accepted: 29 October 2014 \\ Author postprint version - The final publication is available at : \\ http://link.springer.com/article/10.1007/s00267-014-0398-4
}

\begin{abstract}
Vegetation management often involves shredding to dispose of cut plant material or to destroy the vegetation itself. In the case of invasive plants, this can represent an environmental risk if the shredded material exhibit vegetative regeneration capacities. We tested the effect of shredding on aboveground and below-ground vegetative material of five ornamental widespread invaders in Western Europe that are likely to be managed by cutting and shredding techniques: Buddleja davidii (butterfly bush, Scrophulariaceae), Fallopia japonica (Japanese knotweed, Polygonaceae), Spiraea $x$ billardii Hérincq (Billard's bridewort, Rosaceae), Solidago gigantea (giant goldenrod, Asteraceae) and Rhus typhina L. (staghorn sumac, Anacardiaceae). We looked at signs of vegetative regeneration and biomass production, and analyzed the data with respect to the season of plant cutting (spring vs summer), the type of plant material (aboveground vs below-ground) and the shredding treatment (shredded vs control). All species were capable of vegetative regeneration, especially the below-ground material. We found differences among species, but the regeneration potential was generally still present after shredding despite a reduction of growth rates. Although it should not be excluded in all cases (e.g. destruction of giant goldenrod and staghorn sumac aboveground material) the use of a shredder to destroy woody alien plant material cannot be considered as a general management option without significant environmental risk.
\end{abstract}

Keywords : roadside management, green waste, biological invasions, clonal growth, bud bank, crushing, mulching.

\section{Introduction}

Alien plants invasions represent an increasing problem for green spaces (Gelbard and Belnap 2003). For an increasing number of species, eradication is no longer realistic (Rejmánek and Pitcairn 2002) and other management options, such as repeated cutting, are considered in order to limit the development of existing populations (Wittenberg and Cock 2001). Whereas cutting methods have been reported to successfully hamper invasions (Delbart et al. 2012; Wittenberg and Cock 2001; Levy et al. 2011), they harvest substantial amounts of invasive plant material. In species capable of vegetative reproduction, plant fragments represent vegetative propagules that can establish new populations and enhance invasion (Bímová et al. 2003; Eriksson 1993; Weber 2011). In this context, it is important to consider the fate of the plant material harvested in cutting campaigns and that land managers need a disposal method that is legal, cost effective and efficient in reducing further invasions (De Waal 2001). One option is to destroy the harvested plant material by the use of a mower and/or shredder, in situ. This technique is considered efficient on the invasive herbaceous Ambrosia artemisiifolia L. (Chauvel and Martinez 2013). On the other hand, De Waal reported that cutting and shredding was used in control campaigns of Japanese knotweed in the UK, but was abandoned due to vegetative growth from shredded material. To our knowledge, no data is available about the uses and the limits of this technique on other invasive plants. 
In addition, vegetation mowing and shredding can be used by green space managers along roads and railways, as well as in parks and flowerbeds (Kohlhepp et al. 1995). The shredded material can then be used as an on-site produced mulch, which has the advantages of reducing weed development (Lanphear and Spangler 1996) and water evaporation (Mulumba and Lal 2008) and limiting the need for plant material transportation. Many green spaces have become novel ecosystems (Seastedt et al. 2008), including a significant proportion of alien plants escaped from gardens (Kowarik 2011; DehnenSchmutz et al. 2007). In places where adaptive management has not yet been implemented, it is likely that invasive plants are shredded with the rest of the vegetation (Luken and Thieret 1997) . However, despite the number of ornamental plant invaders found along roads and railways, as well as in other places commonly managed by mowing and shredding, little is known about the vegetative regeneration capacity of shredded invasive plant material, and the risk it represents for the environment (but see De Waal 2001; Song et al. 2013).

Rhizomatous and/or woody ornamental plants often show good vegetative reproduction (Davies et al. 1994).The vegetative fragment size and the cutting period may have considerable impact on vegetative regeneration capacity (De Waal 2001; Cordazzo and Davy 1999; Weber 2011; Lin et al. 2012). In the present study, we focused on five ornamental widespread invaders in Western Europe that are likely to be managed by cutting techniques (Levy et al. 2011) and have woody tissues that can technically be shredded and used as mulch: Buddleja davidii (Franch.)(butterfly bush, Scrophulariaceae); Fallopia japonica (Houtt.) Ronse Decraene var. japonica (Japanese knotweed, Polygonaceae); Spiraea $x$ billardii Hérincq (Billard's bridewort, Rosaceae, supposedly an hybrid between Spiraea alba and Spiraea douglasii); Solidago gigantea Ait. (giant goldenrod, Asteraceae); and Rhus typhina L. (staghorn sumac, Anacardiaceae). We addressed the following questions: i) After passage through a garden shredder, are aboveground and below-ground plant material capable of regenerating new clones if placed on a favorable substrate?; ii) If so, does shredding alter the vigor (i.e. vegetative growth) of new clones?; and iii) Do the vegetative regeneration capacity and vigor of new clones depend on the cutting period, i.e. spring or summer?

\section{Material and methods \\ Study species}

The butterfly bush $B$. davidii is a multi-stemmed shrub, native to Central and Western China. Since its first introduction in Europe in 1869 (Tallent-Halsell and Watt 2009), it has been cultivated as an ornamental and has become invasive in many parts of Europe (TallentHalsell and Watt 2009). The species is mainly found in disturbed areas, such as roadsides and railways (Randall and Marinelli 1996). Its vegetative reproduction from stems, stumps and roots is documented (Tallent-Halsell and Watt 2009). The Japanese knotweed $F$. japonica is a rhizomatous perennial geophyte that was introduced from Japan to Europe in the mid nineteenth century as an ornamental plant and for fodder production (Beerling et al. 1994). It has rapidly spread throughout Europe through vegetative reproduction (Tiébré et al. 2007). Fragments of rhizomes, stems and leaves have been observed to produced new clones (Brabec 1997; Bímová et al. 2003; De Waal 2001) and eradication of this species is considered particularly difficult (Delbart et al. 2012). The giant goldenrod $S$. gigantea is a rhizomatous perennial herb that produces annual aboveground shoots (Weber and Jakobs 2005). Native to North America, it has been introduced in Europe in the eighteenth century as an ornamental plant (Weber 1998). Once established in an area, giant goldenrod is likely to gain dominance due to its clonal growth and high competitive ability (Weber and Jakobs 2005). The Billard's bridewort $S$. $x$ billardii is a sterile horticultural hybrid between $S$. alba et $S$. douglasii, both of which are native to North America (Verloove 2006). It grows mainly in ruderal areas and in riparian habitats, where it reproduces clonally from rhizomes and stem fragments (pers. obs.). The staghorn sumac $R$. typhina L. was deliberately introduced from 
Eastern North America to Europe in the late nineteenth century for its ornamental qualities (Verloove 2006). It was then found to be a good colonizer of dry disturbed spaces such as roadsides and wastelands. Its reproduction in Europe can be both sexual and asexual (suckers growing from the roots).

\section{Plant material collection}

Plant material from the five species was collected in Southern Belgium. Three populations of each species, with a minimum distance of five kilometers between populations, were sampled from July 2012 to September 2012 (henceforth referred to as summer). In each population, approximately ten kilograms of aboveground plant material, i.e. branches and leaves; and approximately ten kilograms of below-ground plant material, i.e. roots and/or rhizomes, were harvested. In May 2013 (referred to as spring), a similar plant material collection was performed.

\section{Glasshouse experiments}

At both seasons, one half of the aboveground and of below-ground plant material collected in each population was shredded using a Saelens Couguar shredder (Saelens, Belgium, Tienen). This professional green waste shredder is composed of hammers and blades, and crushes plant material in pieces typically ranging from 5 to $40 \mathrm{~mm}$. The plant material was passed once in the shredder. Between each shredding operation the shredder was cleaned by shredding native woody plant material. The other half of the collected plant material served as a control. In both seasons, aboveground and below-ground shredded and control plant material from each population was potted in two-liter plastic pots, with five replicates (for each season, five species times three populations, times two types of plant material, times two shredding treatments, times five replicates, totals three hundred pots). For the control plant material, one fragment of ten to fourteen centimeters without obvious damage was planted per pot, with one liter of compost (Terreau universel, La Plaine Chassart, Belgium). Fragments were placed horizontally at a depth of 1 to $2 \mathrm{~cm}$. Aboveground control fragments typically had one node, but sometimes up to three nodes. Belowground control fragments had at least one ramification. For the shredded material, one liter of plant material was mixed with one liter of the same compost. One liter of shredded material represents more plant material than the control fragments, but a part of it was likely buried too deep to allow regeneration, as it was mixed to the compost. Shredding and potting were performed within twenty-four hours after plant material collection. Pots were placed in an unheated glasshouse, then watered and randomized weekly. Every two to three days, the presence of vegetative regeneration was assessed in all pots. Two months after the first regeneration signs were observed in a pot, the aboveground material was collected and the dry biomass was measured after drying at fifty degrees Celsius during twenty-four hours in a drying oven. Pots without observed regeneration were kept in the glasshouse and monitored during three additional months.

\section{Data analyses}

Each species was analyzed separately. In order to analyze the effects of season, plant material, shredding and the interactions thereof on vegetative regeneration (binary variable), we fitted a generalized linear mixed effect model to our data with a binomial error distribution and a logit link function. The random factor population was included in the grouping structure of the model. Chi-square statistics were used to calculate the predictor significance.

The dry biomass data were analyzed with a generalized linear mixed effect model followed by a three-way ANOVA, with shredding, plant material and season as crossed fixed factors. The random factor population was included in the grouping structure of the model. When no vegetative regeneration was observed, dry biomass was treated as zero. Dry biomass data were transformed as $y=\log (x+1)$ to meet the assumption of the statistical analysis. All analyses were performed in $\mathrm{R}$ ( $\mathrm{R}$ Core Team 2014) using the 'Ime4' package (Bates et al. 2014). 
Table 1 Types of aboveground and below-ground plant material used for each studied species and description of collection sites

\begin{tabular}{|c|c|c|c|c|c|c|}
\hline \multirow[t]{2}{*}{ Species } & \multirow{2}{*}{$\begin{array}{l}\text { Aboveground plant } \\
\text { material }\end{array}$} & \multirow{2}{*}{$\begin{array}{l}\text { Undergound plant } \\
\text { material }\end{array}$} & \multicolumn{4}{|c|}{ Plant material collection sites } \\
\hline & & & Location & Latitude $\mathrm{N}$ & Longitude E & Altitude \\
\hline \multirow[t]{3}{*}{ Buddleia davidii } & \multirow[t]{3}{*}{ Stems and leaves } & \multirow[t]{3}{*}{ Roots } & Maizeret & $50^{\circ} 27^{\prime} 37^{\prime \prime}$ & $4^{\circ} 58^{\prime} 54^{\prime \prime}$ & 175 \\
\hline & & & Huy & $50^{\circ} 30^{\prime} 40^{\prime \prime}$ & $5^{\circ} 14^{\prime} 26^{\prime \prime}$ & 113 \\
\hline & & & Engis & $50^{\circ} 34^{\prime} 45^{\prime \prime}$ & $5^{\circ} 23^{\prime} 34^{\prime \prime}$ & 77 \\
\hline \multirow[t]{3}{*}{ Fallopia japonica } & \multirow[t]{3}{*}{ Stems and leaves } & \multirow[t]{3}{*}{ Roots and rhizomes } & Gembloux & $50^{\circ} 33^{\prime} 53^{\prime \prime}$ & $4^{\circ} 41^{\prime} 60^{\prime \prime}$ & 151 \\
\hline & & & Samson & $50^{\circ} 27^{\prime} 57^{\prime \prime}$ & $4^{\circ} 59^{\prime} 36^{\prime \prime}$ & 84 \\
\hline & & & Malonne & $50^{\circ} 27^{\prime} 04^{\prime \prime}$ & $4^{\circ} 50^{\prime} 05^{\prime \prime}$ & 90 \\
\hline \multirow[t]{3}{*}{ Solidago gigantea } & \multirow[t]{3}{*}{ Stems and leaves } & \multirow[t]{3}{*}{ Roots and rhizomes } & Brumagne & $50^{\circ} 28^{\prime} 45^{\prime \prime}$ & $4^{\circ} 56^{\prime} 40^{\prime \prime}$ & 89 \\
\hline & & & Gembloux & $50^{\circ} 33^{\prime} 56^{\prime \prime}$ & $4^{\circ} 42^{\prime} 14^{\prime \prime}$ & 150 \\
\hline & & & Mabompré & $50^{\circ} 06^{\prime} 12^{\prime \prime}$ & $5^{\circ} 46^{\prime} 06^{\prime \prime}$ & 467 \\
\hline \multirow[t]{3}{*}{ Spiraea billardii } & \multirow[t]{3}{*}{ Stems and leaves } & \multirow[t]{3}{*}{ Roots } & Rixansart & $50^{\circ} 43^{\prime} 01^{\prime \prime}$ & $4^{\circ} 30^{\prime} 46^{\prime \prime}$ & 75 \\
\hline & & & Rosière & $50^{\circ} 44^{\prime} 05^{\prime \prime}$ & $4^{\circ} 32^{\prime} 40^{\prime \prime}$ & 91 \\
\hline & & & Vellereux & $50^{\circ} 05^{\prime} 27^{\prime \prime}$ & $5^{\circ} 43^{\prime} 46^{\prime \prime}$ & 402 \\
\hline \multirow[t]{3}{*}{ Rhus typhina } & \multirow[t]{3}{*}{ Stems and leaves } & \multirow[t]{3}{*}{ Roots } & Liège & $50^{\circ} 37^{\prime} 04^{\prime \prime}$ & $5^{\circ} 35^{\prime} 47^{\prime \prime}$ & 67 \\
\hline & & & Marneffe & $50^{\circ} 34^{\prime} 41^{\prime \prime}$ & $5^{\circ} 08^{\prime} 42^{\prime \prime}$ & 146 \\
\hline & & & Ernage & $50^{\circ} 35^{\prime} 22^{\prime \prime}$ & $4^{\circ} 40^{\prime} 39^{\prime \prime}$ & 151 \\
\hline
\end{tabular}

\section{Results}

For all five species considered in this study, vegetative regeneration capacity was observed for control below-ground material, at both seasons (Fig. 1). Except for the butterfly bush, below-ground plant material showed significantly higher regeneration capacity and biomass production than aboveground material (Table 2, Fig.1). All butterfly bush plant material showed comparable vegetative regeneration capacity (Fig. $1 \mathrm{~A}$ ), but shredding reduced biomass production of both aboveground and below-ground material (Fig. 1 B). The season of plant material collection had no effect on vegetative regeneration or biomass production in this species. For Japanese knotweed, shredding strongly reduced vegetative regeneration capacity (Fig. 1 C) and biomass production (Fig. 1 D), although it did not prevent it. In terms of biomass production, belowground plant material was more affected by shredding than the aboveground material. The aboveground material collected in spring was not able of regeneration, be it shredded or not. The aboveground material of the giant goldenrod did not exhibit regeneration capacity, be it shredded or not, even after five months of observation (Fig. 1 E). For the below-ground material collected in spring, shredding prevented regeneration. In contrast the below-ground material collected in summer, shredded or not, w as able of vegetative regeneration. Though, shredding reduced biomass production (Fig. 1 F). All Billard's bridewort plant material showed important vegetative regeneration capacity (Fig. $1 \mathrm{G})$. The effect of shredding on vegetative regeneration depended on the season, reducing the regeneration capacity of the material collected in spring only. The biomass produced by the shredded material was lower than the controls (Fig. $1 \mathrm{H}$ ). The aboveground material of the staghorn sumac, shredded or not, was not able of regeneration (Fig. $1 \mathrm{I}, \mathrm{J}$ ).

\section{Discussion}

Clonality is a common feature in woody alien plants (Pyšek and Richardson 2007). The present study illustrates the potential for vegetative regeneration of rhizomatous and/or woody ornamental alien plant material, even after shredding. The use of a garden shredder to destroy the plant material harvested in alien plant control campaigns, or more generally the mowing/crushing of vegetations that include such species, cannot therefore be seen as a general management option without significant environmental risk. However, our results indicate a lower regeneration potential for aboveground plant material, which is the main object of vegetation management. The vegetative development of a new ramet requires simultaneous or closely subsequent formation of 
accessory shoot meristems and adventitious root primordia (Jeník 1994). These two types of meristems can be present in most parts of woody plants, including stems, leaves, roots, rhizomes, wound callus, etc. (Jeník 1994). However, bud development may vary according to the location of meristems. Harper (1977) defined the bud bank as the hidden populations of dormant meristems. The crucial role of the bud bank in regeneration after disturbances has been documented in various environments (Latzel et al. 2008; Klimešová and Klimeš 2007). Vegetative regeneration from the bud bank can vary with the vertical distribution of buds, the type of plant organ, the phenological stage, the nutrient availability, and the severity of disturbances (Martínková et al. 2004; Klimešová and Klimeš 2007).

Our results also showed that growth rates were substantially reduced after passage through the shredder, as compared to control fragments. As far as shredding does not lead to a higher dispersal of propagules (e.g. if neatly made on site), this method can still be relevant in a more general management program. In this case, the method seems applicable at any time during the vegetation season, except seed set (Delbart et al. 2010). Most alien woody ornamentals indeed produce viable seeds that are not likely to be efficiently destroyed by shredding. In addition, it is necessary to primarily identify which species are present in the vegetation, since recommendations vary according to the species.

Pure staghorn sumac stands can be controlled by repeated cuttings (Wu et al. 2007), ideally followed by the pulling out of roots (Levy et al. 2011). Our results indicate that the aboveground material is not able of massive regeneration and that shredding can help with below-ground material disposal without high environmental risk. The shredded material could even be used to cover the controlled area, in order to prevent the germination of seeds that is favored by an increase in light (Luken et al. 1991). Repeated cuttings also represent a relevant control technique for the giant goldenrod (Pasquier 2011; Levy et al. 2011; Pasche 2007). As far as only the aboveground part of the vegetation is targeted, our study shows that the harvested aboveground material can be left on site and/or shredded and used as mulch (as recommended by Pasquier 2011). Pulling out is also documented as an eradication method for small populations (Pasche 2007). In this case the belowground material can represent an environmental risk, particularly late in the season.

The case of the Japanese knotweed is a little more complex. Despite the fact that shredding considerably reduces vegetative growth from plant fragments, it does not prevent new clones from establishing from the shredded material. If dispersed in the environment, the shredded material may eventually produce as many or more clones as piled stems after a sufficient period of time. In addition it was shown that repeated cuttings, although able to reduce the size and vigor of the clones, did not lead to clone eradication (Delbart et al. 2012; Child and Wade 2000). Seeing this, the utility of shredding Japanese knotweed plant material, and Asian knotweeds in general, is questionable. In our opinion it should only be considered for reducing the volume and vegetative regeneration vigor of the harvest of cutting campaigns, if the risk of dispersal in the environment is managed properly. Mowing and crushing of knotweed stands along roads and railways should always be avoided, especially after spring.

Both the butterfly bush and Billard's bridewort exhibited a high vegetative regeneration capacity from all types of vegetative parts, be it shredded or not. This is not surprising, since cuttings are known to be used in horticultural propagation of these species. The use of a shredder in the management of those species is therefore irrelevant, and represents a potential risk of further dispersal in the environment. The mowing and crushing of vegetations where those species are present should be avoided.

For butterfly bush, alternative management options have been proposed in the literature (Tallent-Halsell and Watt 2009). Young plants may be hand-picked, but attention should be paid to prevent re-invasion of managed sites (Binggeli et al. 1998). Good results were reported after herbicide treatments after cutting the plants down and treating the stumps with 

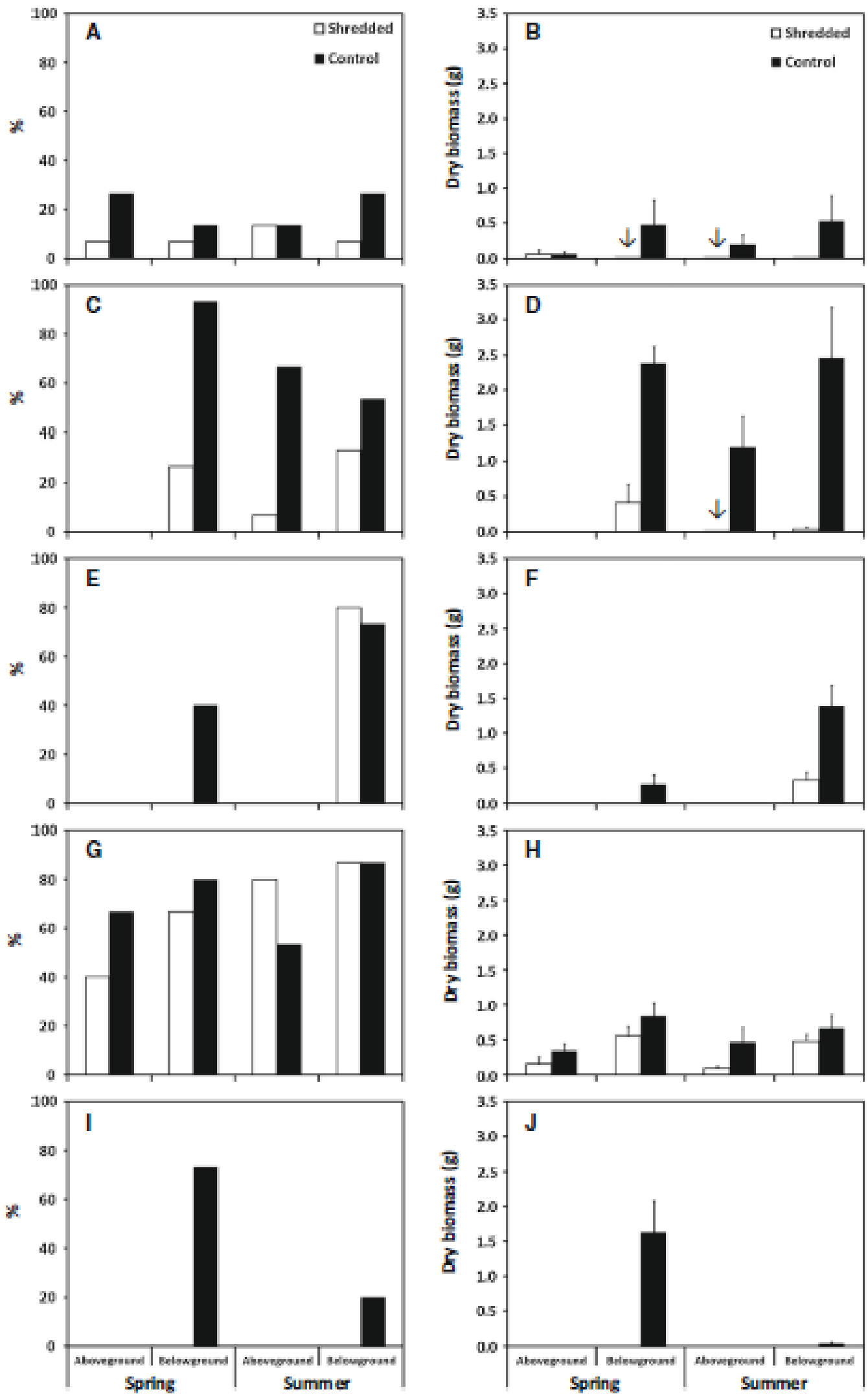

IFig. 1 Percentage of vegetative regenerstion (proportion of pots where vegetafive development was ohserved) and dry hicmas after 2 months (means and standard errors) for the five studied spedies, showing the effects of season (spring vs summer), plant material (hoveground vs helow-ground), and shredding (shredded or controI).

Vertical anows indicate non-zen but extremely low hicmass data 
Table 2 Effects of shredding (shredded or control), plant material (aboveground vs below-ground), and season (spring vs sammer) cen vegetafive regenerstion (hinary variahle) and dry hicmass (contimacas variable) after 2 months, for each studied species

\begin{tabular}{|c|c|c|c|c|c|c|c|c|c|c|}
\hline & \multicolumn{2}{|c|}{ Buddleja davidï } & \multicolumn{2}{|c|}{ Fallapia japonica } & \multicolumn{2}{|c|}{ Solidago gigantea } & \multicolumn{2}{|c|}{ Spiraa $x$ billandï } & \multicolumn{2}{|c|}{ Rhes typhina } \\
\hline & $d f$ & $P$ value & dif & $P$ value & df & P value & dif & P vahe & dif & $P$ value \\
\hline \multicolumn{11}{|c|}{ Vegetative regeneration (analysis of deviance) } \\
\hline Shredding & 1 & 0.063 & 1 & $<0.001$ & 1 & 0.113 & 1 & 0.679 & 1 & $<0.001$ \\
\hline Plant material & 1 & 0.793 & 1 & $<0.001$ & 1 & $<0.001$ & 1 & 0.015 & 1 & $<0.001$ \\
\hline Seascon & 1 & 0.793 & 1 & 0.250 & 1 & $<0.001$ & 1 & 0.110 & 1 & 0.019 \\
\hline Shredding $\times$ plant material & 1 & 0.639 & 1 & 0.051 & 1 & 1.000 & 1 & 0.748 & 1 & 1.000 \\
\hline Shredding $x$ seascn & 1 & 0.694 & 1 & 0.130 & 1 & 0.006 & 1 & 0.041 & 1 & 1.000 \\
\hline Plant material $x$ season & 1 & 0.416 & 1 & $<0.001$ & 1 & 1.000 & 1 & 0.727 & 1 & 1.000 \\
\hline Shredding $x$ plant material $\times$ season & 1 & 0.292 & 1 & 0.999 & 1 & 1.000 & 1 & 0.349 & 1 & 1.000 \\
\hline \multicolumn{11}{|l|}{ Dry hiomass (analysis of variance) } \\
\hline Shredding & 1 & 0.018 & 1 & $<0.001$ & 1 & $<0.001$ & 1 & 0.021 & 1 & $<0.001$ \\
\hline Plant material & 1 & 0.334 & 1 & $<0.001$ & 1 & $<0.001$ & 1 & $<0.001$ & 1 & $<0.001$ \\
\hline Seasn & 1 & 0.758 & 1 & 0.756 & 1 & $<0.001$ & 1 & 0.562 & 1 & 0.872 \\
\hline Shredding $\times$ plant material & 1 & 0.198 & 1 & $<0.001$ & 1 & $<0.001$ & 1 & 0.622 & 1 & $<0.001$ \\
\hline Shredding $x$ season & 1 & 0.497 & 1 & 0.163 & 1 & 0.085 & 1 & 0.937 & 1 & 0.766 \\
\hline Plant material $x$ season & 1 & 0.974 & 1 & 0.002 & 1 & $<0.001$ & 1 & 0.573 & 1 & 0.067 \\
\hline Shredding $\times$ plant material $\times$ season & 1 & 0.725 & 1 & 0.041 & 1 & 0.085 & 1 & 0.531 & 1 & 0.032 \\
\hline
\end{tabular}

For vegetative regenention a generalized linear mixed effect model was fitted with a hincmial error distribution and a logit link function (malysis of deviance). Chi square statisics were used to calculate the predictor significance. The dry hicmass data were analyzed with a generalized linear mixed effect model followed by a thros-way analysis of variance. In both cases, the random fxtor popalation was inchaded in the grouping structure of the model. The statistics provided for each test are the degree of freelom (df) and the associated prohahility ( $P$ value). Significant resalts are in bold

herbicides (Starr et al. 2003; Tallent-Halsell and Watt 2009). However, this is not possible in all habitats due to present restrictions in pesticide use. For Billard's bridewort, we found no management tests in the literature. Further research is needed to properly manage this particular species and woody aliens in general.

Vegetation managers, notably in urban and suburban areas, will increasingly be faced with alien woody species escaped from gardens (Halford et al. 2011; Halford et al. 2014). Although limited to five species among the invasive flora of Western Europe, the present study suggests that attention should be paid to adapt management techniques in order to prevent vegetative propagule dispersal and further spread of invasive plants.

\section{Acknowledgements}

The present study was supported by the Public Service of Wallonia. The authors are grateful to Etienne Branquart, Eric Büchler, M. Halford and Audrey Bourgeois for their helpful comments. All experiments comply with the current laws of the country in which they were performed.

\section{$\underline{\text { References }}$}

Bates D, Maechler M, Bolker B, Walker S (2014) lme4: Linear mixedeffects models using Eigen and S4. R package version 1.1-5.,

Beerling DJ, Bailey JP, Conolly AP (1994) Fallopia Japonica (Houtt.) Ronse Decraene. J Ecol 82 (4):959-979

Bímová K, Mandák B, Pyšek P (2003) Experimental study of vegetative regeneration in four invasive Reynoutria taxa (Polygonaceae). Plant Ecol 166 (1):1-11. doi:10.1023/a:1023299101998

Binggeli P, Hall JB, Healey JR (1998) An overview of invasive woody plants in the tropics. School of Agricultural and Forest Sciences Publication (13)

Brabec (1997) Experimental study of the effect of managment on invasion of selected plant pieces into meadow communities Charles University Prague Czech Republic

Chauvel B, Martinez Q (2013) Allergie à l'ambroisie : quels moyens pour empêcher l'invasion? Revue Française d'Allergologie 53 (3):229-234. doi:http://dx.doi.org/10.1016/j.reval.2013.01.033

Child L, Wade M (2000) The Japanese Knotweed Manual. The Management and Control of an Invasive Alien Weed. Packard, UK, Chichester

Cordazzo CV, Davy AJ (1999) Vegetative regeneration of Panicum racemosum from rhizome fragments on southern Brazilian coastal dunes. Journal of Coastal Research:520-525

Davies F, Jr., Davis T, Kester D (1994) Commercial Importance of Adventitious Rooting to Horticulture. In: Davis T, Haissig B (eds) Biology of Adventitious Root Formation, vol 62. Basic Life Sciences. Springer US, pp 53-59. doi:10.1007/978-14757-9492-2 4

De Waal LC (2001) A viability study of Fallopia japonica stem tissue. Weed Res 41 (5):447-460. doi:10.1046/j.13653180.2001.00249.x

Dehnen-Schmutz K, Touza J, Perrings C, Williamson M (2007) A century of the ornamental plant trade and its impact on invasion success. Diversity and Distributions 13 (5):527-534. doi:10.1111/j.1472-4642.2007.00359.x

Delbart E, Mahy G, Weickmans B, Henriet F, Crémer S, Pieret N, Vanderhoeven S, Monty A (2012) Can Land Managers 
Control Japanese Knotweed? Lessons from Control Tests in Belgium. Environmental Management:1-9. doi:10.1007/s00267-012-9945-z

Delbart E, Pieret N, Mahy G (2010) Les trois principales plantes exotiques envahissantes le long des berges des cours d'eau et plans d'eau en Région wallonne : description et conseils de gestions mécanique et chimique. Gembloux

Eriksson O (1993) Dynamics of genets in clonal plants. Trends in $\begin{array}{lllll}\text { Ecology \& } & \text { Evolution } 8 & \text { (9):313-316 }\end{array}$ doi:http://dx.doi.org/10.1016/0169-5347(93)90237-J

Gelbard JL, Belnap J (2003) Roads as Conduits for Exotic Plant Invasions in a Semiarid Landscape. Conservation Biology 17 (2):420-432. doi:10.1046/j.1523-1739.2003.01408.x

Halford M, Branquart E, Vanderhoeven S, Heemers L, Mathys C, Collin C, Wallens S, Mahy G (2011) AlterIAS: a LIFE+ project to curb the introduction of invasive ornamental plants in Belgium. Aliens: The Invasive Species Bulletin 31:36-41

Halford M, Heemers L, van Wesemael D, Mathys C, Wallens S, Branquart E, Vanderhoeven S, Monty A, Mahy G (2014) The voluntary Code of conduct on invasive alien plants in Belgium: results and lessons learned from the AlterIAS LIFE+ project. EPPO Bulletin 44 (2):212-222

Harper JL (1977) Population biology of plants. Population biology of plants

Jeník J (1994) Clonal growth in woody plants: a review. Folia Geobotanica 29 (2):291-306

Klimešová J, Klimeš L (2007) Bud banks and their role in vegetative regeneration - A literature review and proposal for simple classification and assessment. Perspectives in Plant Ecology, $\begin{array}{llll}\text { Evolution and Systematics } 8 & \text { (3):115-129. }\end{array}$ doi:http://dx.doi.org/10.1016/j.ppees.2006.10.002

Kohlhepp PF, Sanders TG, Tackett CC, Walters RW (1995) Roadside vegetation management.

Kowarik I (2011) Novel urban ecosystems, biodiversity, and conservation. Environmental Pollution 159 (8-9):1974-1983. doi:http://dx.doi.org/10.1016/j.envpol.2011.02.022

Lanphear FO, Spangler RL (1996) Weed Control In Roadside Plantings : Progress Report. Joint Highway Research Project, Indiana Department of Transportation and Purdue University, West Lafayette

Latzel V, Mihulka S, Klimešová J (2008) Plant traits and regeneration of urban plant communities after disturbance: Does the bud bank play any role? Applied Vegetation Science 11 (3):387-394

Levy V, Buchet J, Hauguel J-C, Toussaint B, Valet J-M, Watterlot A (2011) Plantes exotiques envahissantes du nord-ouest de la France. Bailleul

Lin H-F, Alpert P, Yu F-H (2012) Effects of fragment size and water depth on performance of stem fragments of the invasive, amphibious, clonal plant Ipomoea aquatica. Aquatic Botany 99

(0):34-40 doi:http://dx.doi.org/10.1016/j.aquabot.2012.01.004

Luken JO, Hinton AC, Baker DG (1991) Assessment of frequent cutting as a plant-community management technique in power-line corridors. Environmental Management 15 (3):381-388

Luken JO, Thieret JW (1997) Assessment and management of plant invasions. Springer

Martínková J, Klimešová J, Mihulka S (2004) Resprouting after disturbance: an experimental study with short-lived monocarpic herbs. Folia Geobotanica 39 (1):1-12

Mulumba LN, Lal R (2008) Mulching effects on selected soil physical properties. Soil and Tillage Research 98 (1):106-111. doi:http://dx.doi.org/10.1016/j.still.2007.10.011

Pasche D (2007) Gestion des plantes exotiques envahissantes dans le canton de Vaud Centre de Conservation de la faune et de la nature, Vaud

Pasquier J-L (2011) Détermination, lutte et gestion des plantes invasives. Horticulture Romande (11):18-23

Pyšek P, Richardson DM (2007) Traits associated with invasiveness in alien plants: where do we stand? In: Biological Invasions. Springer, pp 97-125
R Core Team (2014) R: A language and environment for statistical computing. R Foundation for Statistical Computing, Vienna, Austria

Randall JM, Marinelli J (1996) Invasive plants: weeds of the global garden. Brooklyn Botanic Garden, New York

Rejmánek M, Pitcairn M (2002) When is eradication of exotic pest plants a realistic goal? In: Veitch CR, Clout MN (eds) Turning the Tide: The Eradication of Invasive Species. IUCN, Campbridge, UK, pp 249-253

Seastedt TR, Hobbs RJ, Suding KN (2008) Management of novel ecosystems: are novel approaches required? Frontiers in Ecology and the Environment 6 (10):547-553. doi:10.1890/070046

Song Y-B, Yu F-H, Li J-M, Keser L, Fischer M, Dong M, Kleunen M (2013) Plant invasiveness is not linked to the capacity of regeneration from small fragments: an experimental test with 39 stoloniferous species. Biol Invasions 15 (6):1367-1376. doi:10.1007/s10530-012-0374-y

Starr F, Starr K, Loope L (2003) Buddleia davidii. United States Geological Survey--Biological Resources Division Haleakala Field Station, Maui, Hawai'i

Tallent-Halsell N, Watt M (2009) The Invasive Buddleja davidii $\begin{array}{lllll}\text { (Butterfly Bush). Bot } \quad \text { Rev } 75 \text { (3):292-325. } & \end{array}$ doi:10.1007/s12229-009-9033-0

Tiébré MS, Bizoux JP, Hardy OJ, Bailey JP, Mahy G (2007) Hybridization and morphogenetic variation in the invasive alien Fallopia (Polygonaceae) complex in Belgium. Am J Bot 94:1900-1910

Verloove F (2006) Catalogue of neophytes in Belgium., vol 39. Scripta Botanica Belgica. National Botanic Garden of Belgium, Meise

Weber E (1998) The dynamics of plant invasions: a case study of three exotic goldenrod species (Solidago L.) in Europe. Journal of Biogeography $25 \quad$ (1):147-154. doi:10.1046/j.13652699.1998.251119.x

Weber E (2011) Strong regeneration ability from rhizome fragments in two invasive clonal plants (Solidago canadensis and $\mathrm{S}$ gigantea). Biol Invasions 13 (12):2947-2955. doi:10.1007/s10530-011-9977-y

Weber E, Jakobs G (2005) Biological flora of central Europe: Solidago gigantea Aiton. Flora - Morphology, Distribution, Functional $\begin{array}{llll}\text { Ecology of Plants } 200 & \text { (2):109-118 }\end{array}$ doi:http://dx.doi.org/10.1016/j.flora.2004.09.001

Wittenberg R, Cock MJW (2001) Invasive Alien Species: A Toolkit of Best Prevention and Management Practices. CABI International, Wallingford, UK

Wu C-h, Zhai M-p, Wang C (2007) Preliminary Study on Control and Prevention from Rhus typhina. Forest Inventory and Planning 6:006 